\title{
A Framework of Indicators for Assessing Construction Automation and Robotics in the Sustainability Context
}

\author{
Mi Pan* \\ Department of Civil Engineering, The University of Hong Kong, Pok Fu Lam, Hong Kong \\ *Corresponding author: Email: panmi@hku.hk, Phone: +852 39178260 \\ Thomas Linner \\ Chair of Building Realization and Robotics, Technical University of Munich, 80333 Munich, \\ Germany \\ Email: Thomas.Linner@bri.arch.tu-muenchen.de \\ Wei Pan \\ Department of Civil Engineering, The University of Hong Kong, Pok Fu Lam, Hong Kong \\ Email: wpan@hku.hk \\ Huimin Cheng \\ Chair of Building Realization and Robotics, Technical University of Munich, 80333 Munich, \\ Germany \\ Email: chm98@126.com \\ Thomas Bock \\ Chair of Building Realization and Robotics, Technical University of Munich, 80333 Munich, \\ Germany \\ Email: Thomas.Bock@bri.arch.tu-muenchen.de
}

\begin{abstract}
Building production" technology, i.e. construction automation and robotics (CAR), is on a worldwide level increasingly recognized as stating a key element of the future of construction, although CAR up to date has never experienced large-scale real-world implementation. However, the recent significantly growing demand for sustainability has the potential to serve as the necessitated trigger for CAR's large-scale deployment. In that context, systematic guidance for the construction industry is however missing, and there have been limited attempts to thoroughly investigate the impacts of utilizing CAR with regard to the sustainability performance of construction and buildings. The research presented in this paper makes a first step to fill this research gap by reviewing and investigating the available CAR strategies and technologies and developing for the first time a consistent framework of indicators for assessing the sustainability performance of utilizing CAR for buildings. The overall goal of the research is to develop, through this framework, a robust and reliable assessment method that can be used in the industrial context to assess the sustainability of building construction projects that consider using CAR. Beyond the development of the indicator framework, the research plan adopting the V-Model approach foresees to translate the framework into an assessment method which will then in several iteration cycles be verified and validated in real world.
\end{abstract}

Keywords: Construction automation and robotics; Sustainability; Building; Indicators; Assessment framework 


\section{Introduction}

The notion of "building construction" is about to change to a notion of "building production". Construction automation and robotics (CAR) is on a worldwide level increasingly recognized as an advanced technology that indeed may in the future similar as in other industries - build the basis for the "production" of buildings. For decades this has triggered a plethora of research and development efforts both in academia and industry. However, CAR (in particular on the construction site) up to date has never experienced large-scale, real-world implementation. A major reason for this is that CAR lacked so far a "killer application", a major reason or circumstance that would have triggered or necessitated its large-scale use. Amongst others, the cost of human labor in construction up to date never was so high that CAR - a rather expensive technology - would have stated a feasible alternative; also, the demanded quality of buildings never urged contractors to use CAR. However, now the growing demand for sustainability may (in particular in combination with economic and productivity factors) serve as a trigger for the large-scale use of CAR. In that context, systematic guidance for construction industry is missing, and there have limited attempts been made to thoroughly investigate the impacts of utilizing CAR with regard to the sustainability performance of construction and buildings. The research presented in this paper, makes a first step to filling this research gap by reviewing and investigating the available CAR strategies and technologies and developing for the first time a consistent framework of indicators for assessing the sustainability performance of utilizing CAR for in the construction industry.

The application of automation and robotics has been recognized as one of the most radical innovations for construction, which has triggered a plethora of research development efforts for decades (Bock, 2015). But the real-world utilization is still in its infancy, and the lack of economic interest is deemed as the main hurdle (Bock, 2015; Cousineau and Miura, 1998; Mahbub, 2008). Meanwhile, the crucial role of the building sector in mitigating climate change and realizing sustainable development goals has been highlighted in global agendas (Paris Agreement, 2015; United Nations, 2015). Nevertheless, sustainable development and innovation in the building industry has always been considered a being problematic in many aspects (Pan and Ning, 2014). Performance gaps, and poor operational and management procedures hinder the achievement of sustainability, and require advanced technologies as a countermeasure (Goodier and Pan, 2010). In this regard, construction automation and robotics (CAR) is considered as a feasible solution to profoundly improve sustainability performance in multiple ways, such as construction waste reduction, natural resources savings, workplace safety improvements, and high-quality living environment (Bock and Linner, 2012; Castro-Lacouture, 2009; Cousineau and Miura, 1998).

Recently, the Europe Union, for example, has started to initiate and fund projects, in which improvements in construction automation and prefabrication shall bring down the cost for eco-friendly, highly energy-efficient components and buildings in order to foster their large-scale adoption in Europe (BERTIM, 2016; ZERO-PLUS, 2016). Furthermore, some construction companies have already used advanced construction technologies to reduce waste and resource consumption (Bock and Linner, 2015), and first approaches are on the way to employ automation and robotics for controlled disassembly of buildings and urban-mining (Lee et al., 2015). Although the literature reviewed indicates attempts to explore the environmental, economic and social advantages of utilizing CAR, their impacts on sustainability performance have not yet been thoroughly investigated in a systematic manner, and the potential adverse impacts remain largely unknown. Sustainability performance may vary among types of 
technologies and circumstances of consideration, requiring a comprehensive indicator system as a reliable assessment tool.

Additionally, incorporating the concept of sustainability into the field of technology management and practice has been investigated by several scholars. For example, Brent and Pretorius (2008) discussed the complexity of utilizing the concept of sustainable development and technology management practices, and established a conceptual framework and a criteria system for assessment. However, most of the research in that context focuses on the development and management of technology (Brent et al., 2006; Phaal et al., 2004), lacking a focused analysis of the impacts on sustainability by the adoption of a specific (not considered as green) technology. Also, CAR technologies have not been explicitly examined within the sustainability context.

Therefore, this paper develops a bespoke indicator framework of Construction Automation and Robotics for Sustainability Assessment Method (CARSAM), which can underpin the sustainability assessment of utilizing CAR for buildings. The framework should offer decision-making guidance to projects and enterprises on the use of automated and robotic construction technology regarding sustainability issues. The primary scope is limited to building construction; many aspects may be transferrable to civil engineering which are for now not in the scope of this paper. The framework of indicators is primarily and in a systematic manner developed through a synthesis review of literature on both sustainability assessment and CAR. The proposed indicator set covers the impacts of CAR on sustainability performance both at the project and the corporate level, and in conjunction with the relevant intrinsic technological factors.

\section{Background}

In order to prepare the foundation for the review, and clearly define the boundary delimitation of the research, this chapter presents and discusses the development background of CAR and sustainability assessment methods in the construction industry.

\subsection{Development of CAR}

While CAR generally covers a diversity of technologies (Bock and Linner, 2015; Paulson Jr, 1985; Zavadskas, 2010), there is still a lack of consensus on a clear definition. Scholars have proposed various definitions with regard to "construction automation", “construction robotics” or "construction robot”. Skibniewski (1992) defined construction automation as the engineering of any construction process using teleoperated, numerically controlled, semi-autonomous or autonomous equipment, while construction robotics is defined as advanced construction equipment capable of being teleoperated, acquisition and analysis of sensory data, and the execution of numerically controlled or autonomous tasks. Mahbub (2008) defined that CAR equals to the use of self-control mechanical and electronic machinery with intelligent control mechanisms to conduct construction tasks and operations automatically. The used terms and definitions overlap in use, covering systems from mechanical machinery manipulated by the human, to semi-automated or automated devices with remote control, to autonomous robots with more sensors and automated control features. For the purpose of this study, CAR is considered in a boarder sense as including a wide spectrum of machinery and applications for automating construction-related processes in the whole life-cycle of the project (examples as in Fig. 1).

Historically, the first introduction of automation in construction can be traced back 
to the manufacturing of industrialized building components and the prefabrication of modular homes in Japan in the 1970s (Bock and Linner, 2015). That introduction laid the foundation for later worldwide exploration of automation in construction. In the 1980s, many single-task prototype robots have been developed, primarily in the consideration of the low productivity and possible future labor shortfall issues. Later on, full-scale application of on-site automated construction was introduced, with the first building project completed in 1991 in Japan (Bock and Linner, 2016a). The adoption of on-site automated construction systems has demonstrated multiple benefits including a substantial reduction of waste, significant time saving, flexible working conditions, and improved quality, but a high capital expenditure (Bock and Linner, 2016b; Hasegawa, 1999). Japan is the leading country in the research and development (R\&D) of CAR, driven by many large contractors, while in North American, Europe, and other parts of the world, the driving force is from the Universities with few realworld applications (Mahbub, 2008). Due to the limited payoffs of the technology and price competition in the construction market, Japanese companies slow down the investments and research efforts in CAR since the 2000s after the burst of the economic bubble (Mahbub, 2008). Recently, the actual R\&D activities on a worldwide level are concentrating more on the information and communication technologies (ICT) for design and scheduling, drones for monitoring and tracking, additive manufacturing techniques and 3D printing for building construction (Quezada et al., 2016).

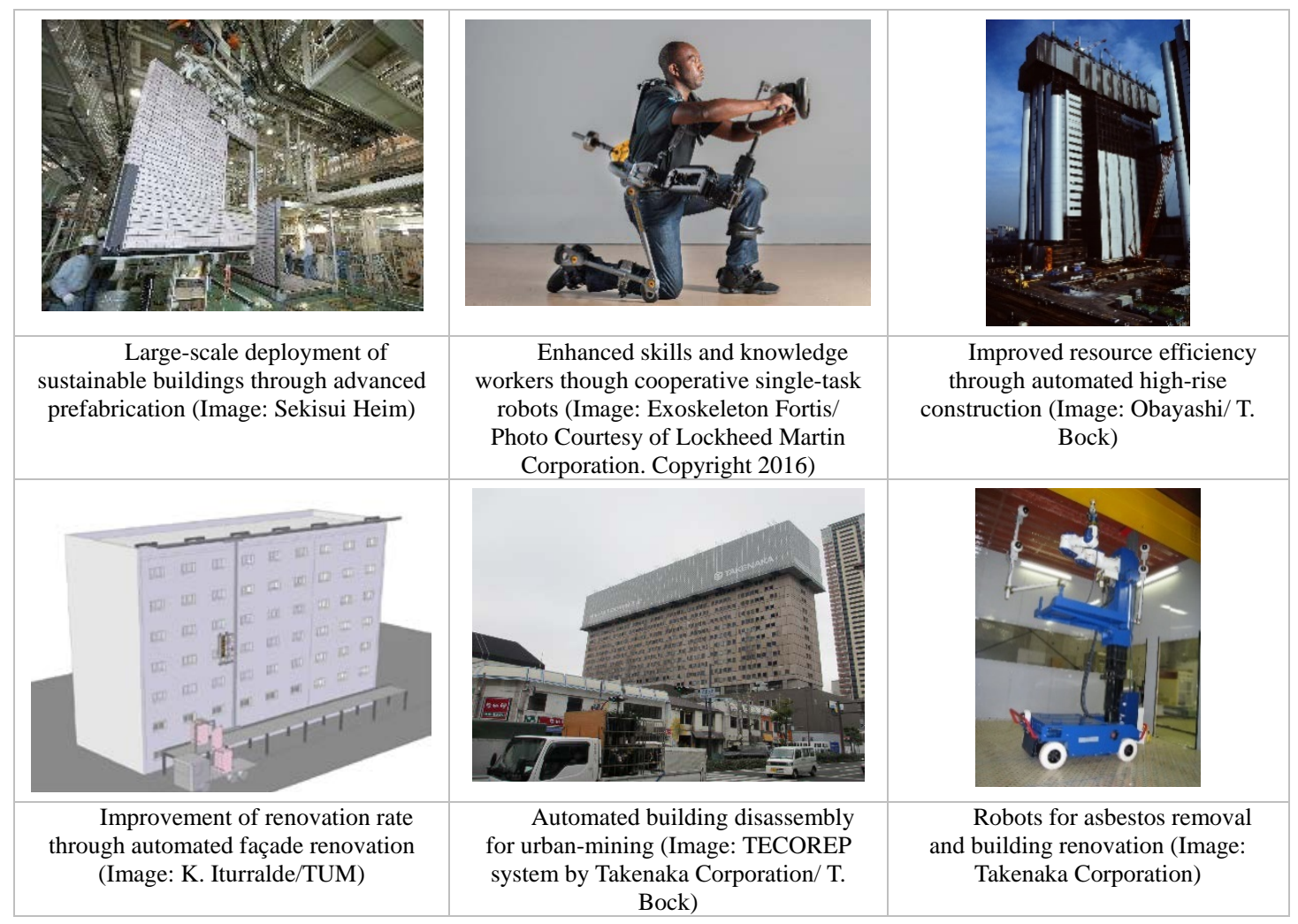

Fig. 1. Examples for CAR for buildings (Pan et al., 2016).

Practices and research activities within the fields of CAR can be classified in many ways. Son et al. (2010) divided the research conducted in the context of automation and robotic technology in construction along the project life-cycle into five main areas: 1) planning and design, 2) construction robotics, 3) intelligent job-site management, 4) operation and maintenance, and 5) others. Struková and Líška (2012) sub-divided construction robots and automation technology into three categories: enhancement to 
existing construction plants and equipment, task-specific robots, and intelligent or cognitive machines. Bock (2015) summarized and categorized the future trend of CAR into five fields: 1) robot-oriented design, 2) robotic industrialization, 3) construction robots, 4) site automation, and 5) ambient robotics.

\subsection{Development of sustainability assessment methods}

Sustainable development, or sustainability, is widely recognized as "development that meets the needs of the present without compromising the ability of future generations to meet their own needs”, as per the widely adopted definition provided by the World Commission on Environment and Development (Brundtland, 1987). In the building and construction industry, sustainability has been described in different ways using the terms "sustainable construction" or "sustainable building” (Berardi, 2013; Pan and Ning, 2015). Kibert (1994) proposed an early definition of sustainable construction as the production of a healthy built environment in light of resourceefficient and ecological principles in the First International Conference on Sustainable Construction. The term sustainable building appears in journal papers since 1996, and its use increased steadily since then (Pan and Ning, 2014), and it describes a particular building or demonstrates a comprehensive approach for the sustainable development of built environment.

Principles and sustainability assessment methods have been extensively developed to interpret the concept of sustainability and to guide real world practice. For instance, Hill and Bowen (1997) proposed principles related to social, economic, biophysical and technical aspects, to be combined with a batch of comprehensive, process-oriented principles to form checklists for real practice in sustainable construction. ISO (2008) emphasized that sustainable development in buildings implies systemic consideration of sustainability for continual improvement and equity, which is a holistic and transparent approach based on the precautionary principle, involving different stakeholders (with different responsibilities assigned), considering the global and local context, from a long-term perspective. Despite the differences most of the studies share as a commonality to use a sustainability framework linked to triple bottom line (TBL) aspects, i.e. economic, environmental and social (ISO, 2008; Labuschagne et al., 2005).

\section{Research methodology}

The overall goal of our research is to develop, through an indicator framework, an assessment method that can be used in the industrial context to assess the sustainability of building construction projects that use advanced construction technology, namely CARSAM. The research presented in this paper is to develop the initial indicator framework through the overall research procedures illustrated in Fig. 2. It was discovered that similar approaches have been widely used in the existing literature to develop indicators and evaluation systems in the fields of sustainable development (Labuschagne et al., 2005; Zhao et al., 2012). There are numerous initiatives on sustainability indicators and frameworks ranging from the international, national, industry, and corporation level on the one end of the scale to the project level (Singh et al., 2009) on the other hand of the scale. First, the conceptual framework is developed, which provides a system to structure and select the indicators for assessment (Zhao et al., 2012). Maclaren (1996) classified the frameworks into six major types: 1) domainbased, 2) issue-based, 3) goal-based, 4) sectoral, 5) cause-effect and 6) combination. Combination frameworks integrate several individual frameworks in order to overcome 
the disadvantages of individual ones, and therefore are considered as preferable (Maclaren, 1996). In this paper, the combination of domain-based and issue-based approaches is adopted to develop the conceptual framework. The systems theory is applied to define the factors both at the project level and corporate level, considering that the construction industry is project-oriented, and CAR technologies, in general, state assets that belong to and enterprise. Additionally, technological factors are embraced and the performance issues relate to CAR for sustainability are identified from literature to further refine the conceptual framework, based on which, performance issues are identified. In the last stage, the identified performance issues are translated into the specific set of indicators based on the defined criteria.

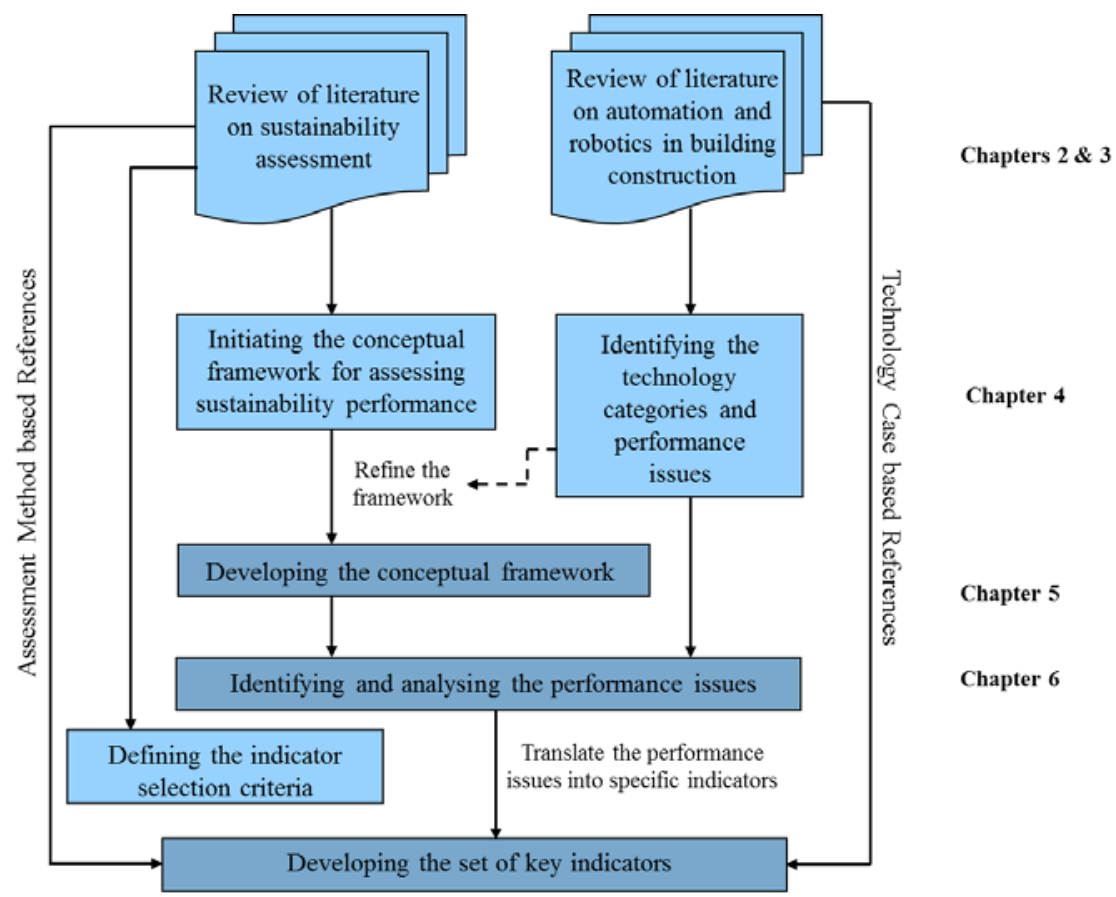

Fig. 2. The overall research procedure to develop the indicator framework.

A synthetic literature review is carried out to develop the conceptual framework and identify the sustainability performance issues of CAR, which means research and development in the area of sustainability assessment and CAR were reviewed in parallel, and then a critical interpretive synthesis was conducted to linking empirical studies on CAR to studies on sustainability assessment. Following literature sources were mainly used:

(a) Academic papers, major databases, including Web of Science, Science Direct, Scopus, Taylor, ASCE were used where a search using related keywords such as 'construction automation and robotics', 'sustainability indicators', 'sustainable building construction' were conducted.

(b) Books and projects on automation and robotics in building construction.

(c) International standards on sustainability in building construction, such as: ISO 15392, ISO 21929-1, and ISO 21931.

(d) International initiatives on indicator frameworks for sustainable development in general, such as the United Nations Commission on Sustainable Development (UNCSD) framework, and the global reporting initiative (GRI) framework.

In order to explore and analyze the potential impacts of technology on 
sustainability in comparison with manual labor based construction, three main categories of CAR are reviewed in-depth: 1) automation in prefabrication, 2) singletask construction robots, and 3) automated/robotic on-site factories (AROFs). Automation in prefabrication or robotic industrialization refers to the use of CAR for the production of customized and prefabricated components and modules (Bock and Linner, 2015). Prefabrication as an innovative way of construction enables strategies from the manufacturing sector, like mass production, to be applied. It allows for mechanization, automation, and robotization to be diffused into the construction industry (Neelamkavil, 2009). Automation in prefabrication is considered as having the ability to control the continuous flow of energy, resources, information and workforce throughout the life-cycle of a boiling, achieving sustainability in every aspect of the TBL (Bock and Linner, 2015). Single-task construction robots, including elementary technologies and single-task robots, are designed for a single, specific construction task, to be conducted in a repetitive manner (Bock and Linner, 2016a). Examples are: mobile handling robots, concrete finishing robot, ceiling board installation robots, and fire proofing robots (Castro-Lacouture, 2009; Cousineau and Miura, 1998). These robots can help to execute repetitive, dangerous or sophisticated works, relieving pressures on labor shortage and skill mismatch, but also challengeable since they can hardly be cooperative with human beings and be integrated with upstream and downstream processes (Bock and Linner, 2016a). AROFs are complete and integrated on-site automation systems used mainly in high-rise construction (Bock and Linner, 2016b; Hasegawa, 1999). The prefabrication of building components off-site and centralized control of construction robots are prerequisites of adopting on-site AROFs (CastroLacouture, 2009).

\section{The conceptual framework of sustainability issues of CAR}

Indicator frameworks are developed to address the diversified sustainability issues in different sectors. For the purpose of this paper, frameworks relevant to construction industry, technology, or innovation are of particular interest. From the perspective of construction industry, Sarkis et al. (2010) developed a strategic and activity-based benchmarking framework for sustainability in construction industry, combining LEED specific indicators and TBL general indicators; ISO 21929-1:2011 defined the core indicators for sustainable building covering the potential impacts to the different areas of concern, including 1) environmental: impacts to resources and environment, 2) economic: economic value and productivity, and 3) social: health, satisfaction, cultural value, and equity. From the perspective of technology assessment, Dunmade (2002) established the indicator framework for assessing the sustainability of a foreign technology, combing TBL factors with the technical sustainability factors as the fourth aspects; Labuschagne et al. (2005) proposed an operational sustainability indicator framework for industry activates along the three aspects of TBL, which has been applied for the technology assessment in a variety of industries (Brent and Pretorius, 2008; Brent et al., 2006). 


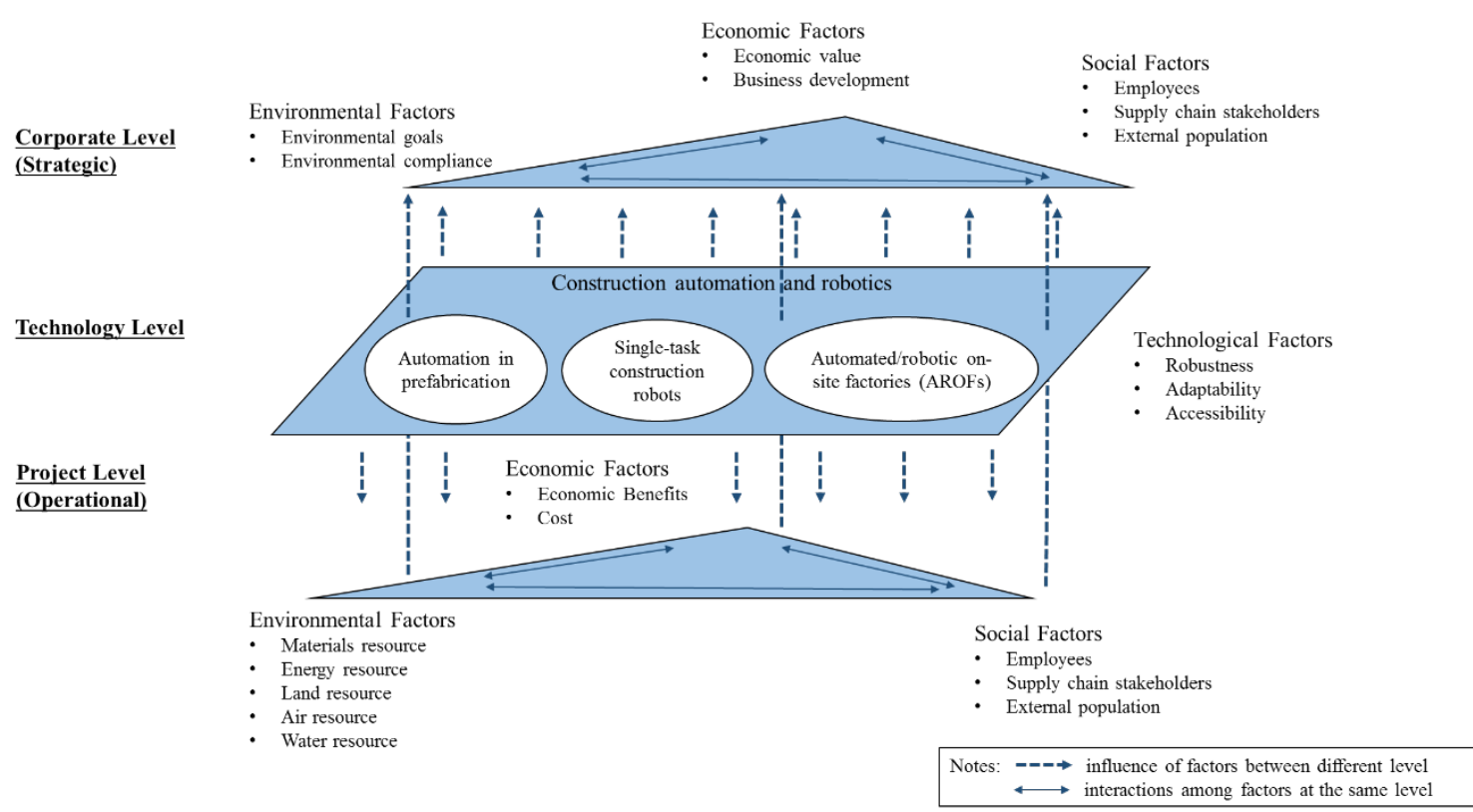

Fig. 3. The conceptual framework of sustainability issues of CAR.

By comparing the similarities and differences of the research focus of existing frameworks with the focus of this paper, the combination of domain-based and issuebased approaches is applied to develop the conceptual framework, as demonstrated in Fig. 3. Three domains, namely 1) environmental, 2) economic, and 3) social, are defined on the project and corporate level. Also, factors affecting the technological performance of CAR are considered as a fourth domain on the technology level. Key issues which CAR can affect are identified in each domain. Interactions exist among all the factors at the same level, whereas factors at the project level are influential to sustainability performance at the corporate level.

\section{Identification of sustainability performance issues of CAR}

On the basis of the conceptual framework, sustainability performance issues related to CAR are initially identified and discussed in this chapter, and will be specifically elaborated in the next chapter.

\subsection{Performance issues at the project level}

At the project level, the employment of CAR can affect the project performance on TBL aspects via the optimization of the construction processes, resource utilization, recycling mechanisms, replacement of human workers in hazardous and heavy jobs, etc. (Pan et al., 2016). Specifically, environmental performance issues touch upon the use of resources and impact on the environment with regard to materials, energy, land, air and water resources; economic performance issues cover the potential economic benefits gained by the use of CAR, and associated costs; social performance issues are identified in light of the well-being, such as the health and safety, of project stakeholders, including employees, supply chain stakeholders, and external populations (Brent and Pretorius, 2008; Brent et al., 2006; ISO, 2008; Labuschagne et al., 2005; Yuan, 2013).

\subsection{Performance issues at the corporate level}

At the corporate level, the focus has been changed from the cross-enterprise 
project to the project-oriented enterprise to probe the TBL performance concerns. Most of the environmental issues are directly embodied in the projects themselves, and therefore potential influences are examined strategically on the achievement of environmental goals and compliance with environmental legislation, policies and standards (Qi et al., 2010). In the competitive and profit-driven market, economic performance is crucial to the construction firms, and issues are discussed in long-term economic value and business opportunities on the investment of technology (Brent and Pretorius, 2008). Social performance issues are explored in the same stakeholder groups and as per project level but extend to the widespread influence beyond the project, such as the culture development and industry well-being (Brent et al., 2006).

\subsection{Performance issues at the technology level}

At the technology level, technological factors in terms of robustness, adaptability and accessibility are taken into account, which are pertinent for realizing the expected performance for sustainable development (Assefa and Frostell, 2007; Brent and Pretorius, 2008; Dunmade 2002). Robustness refers to the validity and reliability of the technology during operation. Adaptability is the capability of the technology to be utilized under a variety of different working circumstances and be coordinated with different objects. Accessibility deals with whether the machine and its components are easily accessible and acceptable in the foreseen application scenarios. Factors beyond the concerned life-cycle period of the technology, such factors bound to energy, cost for manufacturing, and dismantling, are excluded.

\section{Identification of sustainability indicators of CAR}

To be able to extract and describe feasible indicators based on literature review and the analysis of existing systems that are in tune with the identified performance issues, a set of criteria was defined that shall govern the selection process (Reed et al., 2006):

a) Measurable: be easily measured quantitatively or qualitatively.

b) Relevant: directly relates to a meaningful and purposeful aspect under evaluation.

c) Understandable: be interpreted by targeted audiences.

d) Reliable: be reliable and accurately describe the underlying issues.

e) Data accessible: be based on data and information which can be easily accessed and obtained.

f) Cost: be cost-effective to measure.

g) Timely manner: provide timely information.

Based on these criteria, a specific set of indicators was extracted from the analyzed literature and case studies. The indicators were determined by a synthesis review. Table $1-4$ show the extracted indicators (per indicator main category) that are able to describe and assess the environmental performance of CAR, the performance issue the address, the category to which they belong and the indicator's origin.

\subsection{Indicators of the environmental performance}

Environmental performance has often been emphasized in building assessment in the context of sustainability. Operationally, the application of CAR can engender a 
series of potentially positive and negative environmental impacts, such as material use optimization, waste minimization, consumption of additional energy for operation, etc. Strategically, the improvement of environmental performance also plays an essential role in achieving environmental goals of enterprises and compliance with regulatory requirements.

Table 1. Indicators of the environmental performance of CAR.

\begin{tabular}{|c|c|c|c|}
\hline Categories & $\begin{array}{l}\text { Performance } \\
\text { Issues }\end{array}$ & Key Indicators & References \\
\hline \multirow{3}{*}{$\begin{array}{l}\text { Materials } \\
\text { resource }(* \mathrm{P})\end{array}$} & \multirow[b]{2}{*}{$\begin{array}{l}\text { Material } \\
\text { consumption }\end{array}$} & $\begin{array}{l}\text { Raw material consumption } \\
\text { saving }\end{array}$ & $\begin{array}{l}\text { (Cousineau and Miura, } \\
\text { 1998; Lee et al., 2015) }\end{array}$ \\
\hline & & Material recycling & $\begin{array}{l}\text { (Bock and Linner, 2015; } \\
\text { Lee et al., 2015; } \\
\text { Neelamkavil, 2009) }\end{array}$ \\
\hline & Solid waste & $\mathrm{C} \& \mathrm{D}$ waste reduction & $\begin{array}{l}\text { (Bock and Linner, 2015; } \\
\text { Cousineau and Miura, } \\
\text { 1998) }\end{array}$ \\
\hline \multirow{4}{*}{$\begin{array}{l}\text { Energy } \\
\text { resource }(\mathrm{P})\end{array}$} & \multirow{2}{*}{$\begin{array}{l}\text { Energy } \\
\text { consumption }\end{array}$} & $\begin{array}{l}\text { Energy saving in process } \\
\text { refinement }\end{array}$ & $\begin{array}{l}\text { (Bock and Linner, } \\
\text { 2016b; Hong et al., } \\
\text { 2015) }\end{array}$ \\
\hline & & $\begin{array}{l}\text { Energy consumption for } \\
\text { operation }\end{array}$ & $\begin{array}{l}\text { (Bock and Linner, } \\
\text { 2016b; Hong et al., } \\
\text { 2015) }\end{array}$ \\
\hline & \multirow{2}{*}{ GHG emission } & $\begin{array}{l}\text { GHG emissions saving in } \\
\text { process refinement }\end{array}$ & $\begin{array}{l}\text { (Bock and Linner, } \\
\text { 2016b; Hong et al., } \\
\text { 2015) }\end{array}$ \\
\hline & & GHG emissions in operation & $\begin{array}{l}\text { (Bock and Linner, } \\
\text { 2016b; Hong et al., } \\
\text { 2015) }\end{array}$ \\
\hline \multirow{4}{*}{$\begin{array}{l}\text { Land resource } \\
\text { (P) }\end{array}$} & \multirow{4}{*}{ Land consumption } & Site land consumption saving & (Balaguer et al., 2002) \\
\hline & & $\begin{array}{l}\text { Land saving in waste } \\
\text { landfilling }\end{array}$ & (Yuan, 2013) \\
\hline & & Impact on urban mining & (Lee et al., 2015) \\
\hline & & $\begin{array}{l}\text { Space requirement for } \\
\text { operation and storage }\end{array}$ & $\begin{array}{l}\text { (Bock and Linner, } \\
\text { 2016b) }\end{array}$ \\
\hline \multirow{2}{*}{$\begin{array}{l}\text { Air resource } \\
\text { (P) }\end{array}$} & Air pollution & Air pollution reduction & $\begin{array}{l}\text { (Bock and Linner, 2015; } \\
\text { Cousineau and Miura, } \\
\text { 1998; Yuan, 2013) }\end{array}$ \\
\hline & Noise emission & Noise emission reduction & $\begin{array}{l}\text { (Bock and Linner, } \\
\text { 2016b; Khoshnevis, } \\
\text { 2004; Yuan, 2013) }\end{array}$ \\
\hline \multirow{3}{*}{$\begin{array}{l}\text { Water } \\
\text { resource }(\mathrm{P})\end{array}$} & \multirow{2}{*}{ Water use } & Water consumption saving & $\begin{array}{l}\text { (Cousineau and Miura, } \\
\text { 1998) }\end{array}$ \\
\hline & & Water recycling & $\begin{array}{l}\text { (Cousineau and Miura, } \\
\text { 1998) }\end{array}$ \\
\hline & Water pollution & Water pollution reduction & (Yuan, 2013) \\
\hline $\begin{array}{l}\text { Environmental } \\
\text { goals }(* * C)\end{array}$ & $\begin{array}{l}\text { Environmental } \\
\text { goals }\end{array}$ & $\begin{array}{l}\text { Impacts on the achievement of } \\
\text { environmental goals }\end{array}$ & (Qi et al., 2010) \\
\hline \multirow{2}{*}{$\begin{array}{l}\text { Environmental } \\
\text { compliance } \\
\text { (C) }\end{array}$} & \multirow{2}{*}{$\begin{array}{l}\text { Environmental } \\
\text { compliance }\end{array}$} & $\begin{array}{l}\text { Compliance with } \\
\text { environmental legislation }\end{array}$ & $\begin{array}{l}\text { (Dunmade, 2002; Pan } \\
\text { and Garmston, 2012; Qi } \\
\text { et al., 2010) }\end{array}$ \\
\hline & & $\begin{array}{l}\text { Compliance with } \\
\text { environmental policies }\end{array}$ & $\begin{array}{l}\text { (Dunmade, 2002; Pan } \\
\text { and Garmston, 2012; Qi } \\
\text { et al., 2010) }\end{array}$ \\
\hline
\end{tabular}




\begin{tabular}{|l|l|l|} 
& $\begin{array}{l}\text { Compliance with } \\
\text { environmental standards }\end{array}$ & $\begin{array}{l}\text { (Dunmade, 2002; Pan } \\
\text { and Garmston, 2012; Qi } \\
\text { et al., 2010) }\end{array}$ \\
\hline
\end{tabular}

${ }^{*} \mathrm{P}$ : indicators considered at the project level; ${ }^{* *} \mathrm{C}$ : indicators considered at the corporate level

\subsubsection{Material recourse}

Generally, the machine can do the job more precisely and efficiently. Automated approaches can catalyze the efficient use of materials in many ways. For instance, the optimization of resource utilization can be achieved by systematic scheduling and automation in prefabrication factories under dynamic circumstances. Sensor-based control can not only track the material and components for better interactions, but also detect the geometry of waste component for reuse (Neelamkavil, 2009). With CAR, the collection and sorting of waste can be well harmonized and integrated into the prefabrication process (Bock and Linner, 2015). Reduced waste is also an apparent benefit of $\mathrm{A} / \mathrm{ROFs}$, according to the tests of existing prototypes. The first applied $\mathrm{A} / \mathrm{ROF}$ in the world, named SMART, achieved a 70\% reduction in waste with the integration of off-site prefabrication and on-site automation (Cousineau and Miura, 1998). A/ROFs can also allow materials and components to be reused in a straightforward way and by utilizing BIM in combination with CAR (Lee et al., 2015). Consequently, compared to manual labor, automation and robotics can result in savings with regard to raw material consumption, material recycling, and reduction of construction and demolition (C\&D) waste.

\subsubsection{Energy recourse}

Energy consumption and GHG emissions are two of the most common parameters in assessing sustainability performance of buildings during the building operation phase (Berardi, 2013). To assess CAR, energy performance may lie in the facility and machinery use. Automation and robotics can contribute to a leaner working process to optimize the associated energy (Bock and Linner, 2016b). However, some automated machines or robots may themselves during their operation consume a lot of energy, and release GHG emissions if powered by non-renewable energy (Hong et al., 2015).

\subsubsection{Land resource}

CAR can also affect the effective use of land resource in several ways. Firstly, automated approaches can streamline the site layout and optimize the land use (Balaguer et al., 2002). Secondly, C\&D activities often generate a huge amount of waste, and landfilling is still a key approach to handle the C\&D waste in many countries (Yuan, 2013). CAR can contribute to the reduction of C\&D waste, thereby minimizing space for landfills and soil pollution. Thirdly, CAR facilitates urban mining. For example, with A/ROFs, the building under deconstruction can be systematically dis-assembled instead of being brought down by demolition and/or explosives, and the (steel based) components do not have to be melted down for heavily energy consuming recycling (De Beer et al., 1998) but can be refreshed and reused without the need for major deformation directly in the construction of another building, truing the existing building stock in a mine (Lee et al., 2015). Meanwhile, some automated machines are bulky equipment requiring special working environment, and thus additional land space for their operation and storage is needed.

\subsubsection{Air resource}

C\&D activities can adversely impact on the nearby air quality by causing air pollution and noise emissions (Yuan, 2013). Therefore, CAR could also alleviate the 
harmful impacts on air resources by measures such as reducing waste (Cousineau and Miura, 1998), creating clean and dust emission free working conditions (Khoshnevis, 2004), and accelerating paces of construction works (Bock and Linner, 2016b). Air quality is also closely linked to social impacts.

\subsubsection{Water resource}

Water is one of the fundamental elements in building construction, consumed in tasks like mortar preparation, mixing and curing of concrete, cleaning, etc. Compared to human labor, CAR is conceived being able to more efficiently make use of water resources and water recycling techniques (Cousineau and Miura, 1998). In addition, water contamination resulting from $C \& D$ waste can also be considerably lessened due to the reduction in waste by implementing automation and robotics, since CAR usually comes along with a structured work environment

\subsubsection{Environmental goals}

Companies are held accountable to improve their environmental performance by having to publishing their environmental goals. A better environmental performance ca be achieved by applying automated technologies at the project level (Qi et al., 2010). Therefore, the influence of CAR on environmental goals and how it impacts on those goals should state a key indicator for managers.

\subsubsection{Environmental compliance}

Many countries, regions and cities have introduced environmental legislation, policies, and standards facilitating environmental compliance and to assure the proposed projects will not cause negative environmental impacts (Dunmade, 2002; Pan and Garmston, 2012; Qi et al., 2010). For projects or enterprises that want to improve their environmental performance, the implementation of CAR technologies can serve as a key enabler for achieving compliance with environmental aspects targeting legislation, policies and standards.

\subsection{Indicators related to economic performance}

It is widely acknowledged that the implementation of CAR is always economically difficult due to the high capital cost and maintenance cost related to CAR technology (Cousineau and Miura, 1998; Mahbub, 2008). Its economic performance may vary with different types of technology. Bock and Linner (2016a) reported that practical experience has in the 1980s demonstrated the poor economic performance of the majority of at that time used single-task construction robots. Wakisaka et al. (2000) developed an all-weather automated building construction system for high-rise reinforced concrete buildings, and measurements obtained during the application of the system validated it as a cost-effective way for constructing buildings higher than twenty stories.

Table 2. Indicators of the economic performance of CAR.

\begin{tabular}{|c|c|c|c|}
\hline Categories & Performance Issues & Key Indicators & References \\
\hline \multirow[t]{2}{*}{$\begin{array}{l}\text { Economic } \\
\text { Benefits }(* P)\end{array}$} & \multirow[t]{2}{*}{$\begin{array}{l}\text { Direct economic } \\
\text { benefits }\end{array}$} & Saving in labor cost & $\begin{array}{l}\text { (Abbott, 2013; Bock and } \\
\text { Linner, 2015; Kumar et al., } \\
\text { 2016; Lee et al., 2013; } \\
\text { Warszawski, 2003) }\end{array}$ \\
\hline & & Saving in resource cost & $\begin{array}{l}\text { (Abbott, 2013; Bock and } \\
\text { Linner, 2015; Kumar et al., }\end{array}$ \\
\hline
\end{tabular}




\begin{tabular}{|c|c|c|c|}
\hline & & & $\begin{array}{l}\text { 2016; Lee et al., 2013; } \\
\text { Warszawski, 2003) }\end{array}$ \\
\hline & & $\begin{array}{l}\text { Saving in cost for } \\
\text { waste management }\end{array}$ & $\begin{array}{l}\text { (Kumar et al., 2016; Bock and } \\
\text { Linner, 2015; Yuan, 2013) }\end{array}$ \\
\hline & \multirow[t]{4}{*}{$\begin{array}{l}\text { Indirect economic } \\
\text { benefits }\end{array}$} & Saving in time & $\begin{array}{l}\text { (Abbott, 2013; Bock and } \\
\text { Linner, 2015; Kumar et al., } \\
\text { 2016; Lee et al., 2013) }\end{array}$ \\
\hline & & $\begin{array}{l}\text { Saving in rework } \\
\text { reduction }\end{array}$ & $\begin{array}{l}\text { (Bock and Linner, 2015; Kumar } \\
\text { et al., 2016) }\end{array}$ \\
\hline & & $\begin{array}{l}\text { Improved quality of } \\
\text { works }\end{array}$ & $\begin{array}{l}\text { (Bock and Linner, 2015; Kumar } \\
\text { et al., 2016; Lee et al., 2013; } \\
\text { Warszawski, 2003) }\end{array}$ \\
\hline & & $\begin{array}{l}\text { Incentives for } \\
\text { innovation }\end{array}$ & (Mahbub, 2008) \\
\hline \multirow[t]{5}{*}{ Costs (P) } & \multirow[t]{3}{*}{ Direct costs } & $\begin{array}{l}\text { Capital cost } \\
\text { (Acquisition cost) }\end{array}$ & $\begin{array}{l}\text { (Cousineau and Miura, 1998; } \\
\text { Mahbub, 2008; Kumar et al., } \\
\text { 2016) }\end{array}$ \\
\hline & & Operation cost & $\begin{array}{l}\text { (Cousineau and Miura, 1998; } \\
\text { Mahbub, 2008; Kumar et al., } \\
\text { 2016) }\end{array}$ \\
\hline & & Maintenance cost & $\begin{array}{l}\text { (Cousineau and Miura, 1998; } \\
\text { Mahbub, 2008; Kumar et al., } \\
\text { 2016) }\end{array}$ \\
\hline & \multirow[t]{2}{*}{ Indirect costs } & $\begin{array}{l}\text { Cost for training } \\
\text { workforce }\end{array}$ & $\begin{array}{l}\text { (Kumar et al., 2016; Vähä et al., } \\
\text { 2013) }\end{array}$ \\
\hline & & $\begin{array}{l}\text { Cost for consulting } \\
\text { professionals }\end{array}$ & (Vähä et al., 2013) \\
\hline \multirow{2}{*}{$\begin{array}{l}\text { Economic } \\
\text { Value }(* * C)\end{array}$} & \multirow{2}{*}{$\begin{array}{l}\text { Long-term economic } \\
\text { value }\end{array}$} & Payback period & (Kumar et al., 2016) \\
\hline & & Return on investment & $\begin{array}{l}\text { (Bock and Linner, 2016a; } \\
\text { Kumar et al., 2016) }\end{array}$ \\
\hline \multirow{3}{*}{$\begin{array}{l}\text { Business } \\
\text { development }(\mathrm{C} \\
\text { ) }\end{array}$} & $\begin{array}{l}\text { Business } \\
\text { opportunities }\end{array}$ & $\begin{array}{l}\text { Impacts on trading } \\
\text { opportunities }\end{array}$ & (Brent et al., 2006) \\
\hline & \multirow[t]{2}{*}{$\begin{array}{l}\text { Long-term business } \\
\text { value }\end{array}$} & $\begin{array}{l}\text { Impacts on company's } \\
\text { reputation }\end{array}$ & (Zavadskas, 2010) \\
\hline & & $\begin{array}{l}\text { Impacts on } \\
\text { competitiveness }\end{array}$ & (Bock and Linner, 2015) \\
\hline
\end{tabular}

${ }^{*} \mathrm{P}$ : indicators considered at the project level; ${ }^{* *} \mathrm{C}$ : indicators considered at the corporate level

\subsubsection{Economic Benefits}

A number of direct and indirect economic benefits can be gained from the utilization of CAR to assist, collaborate, or replace human labor. Direct economic benefits primarily involve savings in labor cost, resource cost, and cost for waste management, whilst indirect economic benefits refer to saving in time, rework reduction, improved building quality, and possible government incentives for applying innovation (Bock and Linner, 2015; Mahbub, 2008). These benefits have been well acknowledged in studies on automation in prefabrication. For example, Warszawski (2003) developed technical guidance to underpin industrialization and demonstrated the economic value of mechanization and automation in prefabrication. According to his studies, automation is not only beneficial in labor saving and precision, but reduces design and mould transformation cost for small batch size orders. Abbott (2013) indicated that the automation of manufacturing processes in prefabrication can achieve 
economic gains by reducing labor cost and construction delays. Furthermore, the context of use affects the economic benefits, and labor cost differences between regions cause different levels of benefits related to labor reduction achieved by utilizing automation and robotics. In terms of indirect economic benefits, Kumar et al. (2016) reported that automated instruments are found to dramatically reduce average time consumed for major construction activities, with greatly increased quality of output and reduction in cost incurred for rework and scrap. Incentives for innovation by employing CAR is also regarded as the indirect economic benefits (Mahbub, 2008).

\subsubsection{Costs}

Whilst CAR can create enormous economic benefits, the associated incremental costs are also considerable. Direct costs derived from acquisition, operation and maintenance the automated machine (Cousineau and Miura, 1998; Mahbub, 2008; Kumar et al., 2016). The majority of automated and robotic technologies have a considerable capital cost, especially A/ROFs, which is often regarded as one of the major barriers for real-word adoption (Cousineau and Miura, 1998). Lee et al. (2013) conducted a comparative cost analysis on a building project with four floors constructed in the conventional way while three others were built by an A/ROF. The floor unit cost of the buildings built by A/ROFs was about six times that of the traditional way of building, and evidence shows that the cost will decrease with increasing number of stories of the building and through learning effects with regard to repetitive laments (Lee et al., 2013). In addition, implementing CAR requires a substantial build-up of expertise, leading to indirect costs for training workforce and consulting professionals (Vähä et al., 2013).

\subsubsection{Economic Value}

At the corporate level, financial feasibility for investing CAR can be assessed by long-term economic value in terms of payback period and return on investment (Kumar et al., 2016). Studies show that the economic sustainability can be achieved only when CAR is applied in a repetitive manner (Cousineau and Miura, 1998). Therefore, to enable the robotic technologies being widely adopted by construction organizations, the long-term economic value from the reuse of technology should be sufficiently justified.

\subsubsection{Business development}

CAR also leads to market differentiation, which can reap benefits of business development including business opportunities and long-term business value. As the technology owner or investor, there would be additional trading opportunities (Brent et al., 2006). Furthermore, the reputation benefits as an enterprise of technological innovations can be obtained (Zavadskas, 2010), and technological competitiveness can be achieved (Bock and Linner, 2015), which are conductive to the long-term business development of the corporation.

\subsection{Indicators of the social performance}

In the perspective of social sustainability, CAR can influence the well-being of multiple stakeholders related to a project or company, including stakeholder such as employees, supply chain stakeholders, and external populations. Though social factors have been largely neglected in mainstream studies of sustainable building (Pan and Ning, 2014), the impacts of CAR on people are significant and various, as it serves the purpose of performing tasks which normally ascribed to human workers. 
Table 3. Indicators of the social performance of CAR.

\begin{tabular}{|c|c|c|c|}
\hline Categories & $\begin{array}{l}\text { Performance } \\
\text { Issues }\end{array}$ & Key Indicators & References \\
\hline \multirow{8}{*}{$\begin{array}{l}\text { Employees } \\
(* \mathrm{P})\end{array}$} & \multirow{4}{*}{$\begin{array}{l}\text { Occupational } \\
\text { health and } \\
\text { safety }\end{array}$} & Reduction of injuries and fatalities & (Castro-Lacouture, 2009) \\
\hline & & Reduction of heavy works & (Bock and Linner, 2012) \\
\hline & & $\begin{array}{l}\text { Impacts on physical working } \\
\text { condition }\end{array}$ & $\begin{array}{l}\text { (Bock and Linner, 2012; } \\
\text { Khoshnevis, 2004) }\end{array}$ \\
\hline & & Reduction of working hours & (Bock and Linner, 2012) \\
\hline & \multirow{2}{*}{$\begin{array}{l}\text { Job } \\
\text { satisfaction }\end{array}$} & Improved job satisfaction & (Bock and Linner, 2012) \\
\hline & & Impacts on job security and welfare & $\begin{array}{l}\text { (Mahbub, 2008; } \\
\text { Sandberg et al., 2008) }\end{array}$ \\
\hline & \multirow{2}{*}{$\begin{array}{l}\text { Workforce } \\
\text { development }\end{array}$} & $\begin{array}{l}\text { Providing additional capacity } \\
\text { development }\end{array}$ & $\begin{array}{l}\text { (Bock and Linner, 2012; } \\
\text { Mahbub, 2008) }\end{array}$ \\
\hline & & Improved job attractiveness & (Bock and Linner, 2012) \\
\hline \multirow{3}{*}{$\begin{array}{l}\text { Supply chain } \\
\text { stakeholders } \\
\text { (P) }\end{array}$} & \multirow{3}{*}{$\begin{array}{l}\text { Stakeholders } \\
\text { satisfaction }\end{array}$} & $\begin{array}{l}\text { Improved client and end-user } \\
\text { satisfaction }\end{array}$ & $\begin{array}{l}\text { (Brent et al., 2006; } \\
\text { Mahbub, 2008) }\end{array}$ \\
\hline & & $\begin{array}{l}\text { Impacts on upstream and downstream } \\
\text { tasks in the project }\end{array}$ & $\begin{array}{l}\text { (Bock and Linner, } \\
\text { 2016a) }\end{array}$ \\
\hline & & Impacts on building or unit price & (Bock and Linner, 2012) \\
\hline \multirow{2}{*}{$\begin{array}{l}\text { External } \\
\text { population } \\
\text { (P) }\end{array}$} & \multirow{2}{*}{$\begin{array}{l}\text { Public well- } \\
\text { being }\end{array}$} & $\begin{array}{l}\text { Reduction of project disturbance to } \\
\text { site neighbors }\end{array}$ & $\begin{array}{l}\text { (Bock and Linner, } \\
\text { 2016b; Castro- } \\
\text { Lacouture, 2009; } \\
\text { Khoshnevis, 2004) }\end{array}$ \\
\hline & & $\begin{array}{l}\text { Reduction of environmental impacts } \\
\text { of the project to the local community }\end{array}$ & $\begin{array}{l}\text { (Bock and Linner, } \\
\text { 2016b; Castro- } \\
\text { Lacouture, 2009; } \\
\text { Khoshnevis, 2004) }\end{array}$ \\
\hline \multirow{4}{*}{$\begin{array}{l}\text { Employees } \\
(* * C)\end{array}$} & \multirow{4}{*}{$\begin{array}{l}\text { Culture } \\
\text { development }\end{array}$} & $\begin{array}{l}\text { Improved continuity and stability of } \\
\text { the employment }\end{array}$ & (Goulding et al., 2012) \\
\hline & & Promoting the culture of innovation & $\begin{array}{l}\text { (Pan, 2010; Zavadskas, } \\
\text { 2010) }\end{array}$ \\
\hline & & Impacts on enterprise cohesion & (Mahbub, 2008) \\
\hline & & $\begin{array}{l}\text { Responsibility and accountability } \\
\text { issues }\end{array}$ & $\begin{array}{l}\text { (Mahbub, 2008; } \\
\text { Warszawski and Navon, } \\
\text { 1998) }\end{array}$ \\
\hline \multirow{5}{*}{$\begin{array}{l}\text { Supply chain } \\
\text { stakeholders } \\
\text { (C) }\end{array}$} & Partnership & $\begin{array}{l}\text { Impacts on maintaining the long-term } \\
\text { partner relationship }\end{array}$ & (Brent et al., 2006) \\
\hline & \multirow{3}{*}{$\begin{array}{l}\text { Industry well- } \\
\text { being }\end{array}$} & $\begin{array}{l}\text { Alleviating skilled labor shortage } \\
\text { problems }\end{array}$ & (Bock and Linner, 2012) \\
\hline & & Stimulating technological innovation & $\begin{array}{l}\text { (Pan, 2010; Zavadskas, } \\
\text { 2010) }\end{array}$ \\
\hline & & Reforming labor market & $\begin{array}{l}\text { (Quezada et al., 2016; } \\
\text { Sandberg et al., 2008) }\end{array}$ \\
\hline & $\begin{array}{l}\text { Governmental } \\
\text { approval }\end{array}$ & $\begin{array}{l}\text { Impacts on obtaining the } \\
\text { governmental approval of } \\
\text { construction works }\end{array}$ & (Mahbub, 2008) \\
\hline $\begin{array}{l}\text { External } \\
\text { population } \\
\text { (C) }\end{array}$ & $\begin{array}{l}\text { Job } \\
\text { opportunities }\end{array}$ & $\begin{array}{l}\text { Provision of high-tech job } \\
\text { opportunities }\end{array}$ & $\begin{array}{l}\text { (Bock, 2015; Mahbub, } \\
\text { 2008) }\end{array}$ \\
\hline
\end{tabular}

*P: indicators considered at the project level; ${ }^{* *} \mathrm{C}$ : indicators considered at the corporate level 


\subsubsection{Employees}

Fundamentally, the role of automation and robotics is assisting human employees in conducting the dangerous, monotonous or unreasonable construction jobs also referred to as dull, dirty, and dangerous tasks: DDD tasks) in a more efficient and accurate way. Therefore, these technologies have profound impacts on the well-being of employees.

At the project level, performance issues are considered such as occupational health and safety, job satisfaction, and workforce development. The construction site is characterized by dangerous task where injuries and fatalities can often occur, such as workers falling from roofs or scaffolds, electrocution, and machinery accidents (CastroLacouture, 2009). In this regard, machines can replace human workers in these hazardous, DDD tasks and contribute to a reduction of injuries and fatalities (CastroLacouture, 2009). Additionally, equipped with automation and robotics, negative impacts of construction works on the health of human labors can be mitigated by largely reducing onerous physical works, providing better physical working conditions, reducing working hours, and improved ergonomics of the automated/robotic equipment (Bock and Linner, 2012). All these social benefits could lead to improved job satisfaction (Bock and Linner, 2012). Meanwhile, the introduction of CAR may also exert influence on job security and welfare as tasks are replaced and jobs may be redefined (Sandberg et al., 2008). Recently, new forms of single-task robots, additive manufacturing technologies, exoskeletons, swarm robotic approaches, self-assembling building structures, and even humanoid robot technology for the construction were developed and tested. The trend also goes towards collaborative robots that work together with and assist the human being instead of substituting it. In this respect, human workers are still required to operate complicated robotic machines which reduces job insecurity. Also, workforce development could also be maintained by providing additional capacity for improving the attractiveness of construction on-site jobs to young generations (Bock and Linner, 2012).

At the corporate level, social aspects are key with regard to indicators. Firstly, many types of CAR could facilitate the concentration of construction works to off-site or on-site factories, where automated machines can operate more effectively (as they create a "structured" work environment), which can potentially increase the continuity and stability of the employment (Goulding et al., 2012). Secondly, it can facilitate the corporate culture to continuously improve technological and non-technological innovations (Pan, 2010; Zavadskas, 2010). Thirdly, enterprise cohesion could be affected since CAR changes the organizational structures as well as job profiles, promoting or inhibiting the harmonious interpersonal relationship in the company. Fourthly, unlike manual labor, due to its "unstructured" and "uncontrolled” nature CAR cannot take real responsibility and accountability for works it conducts, especially when incidents or mistakes happened, which is also a leading managerial barrier (Warszawski and Navon, 1998).

\subsubsection{Supply chain stakeholders}

Supply chain relationships in the building sector are often complicated, and linked to elusive ripple effects. From the project perspective, the implementation of advanced construction technologies chiefly affects stakeholder satisfaction, including improved client and end-user satisfaction with the better quality and improved maintainability of the building product, impacts on upstream and downstream tasks in the project, and impacts on the price of the end product (Bock and Linner, 2012; Mahbub, 2008). From the corporate perspective, the investment in automation can exert impacts on 
maintaining the long-term partner relationship. Furthermore, several social issues can arise from the concern of industry well-being, including the capability to alleviate skilled labor shortage problems (Bock and Linner, 2012), to invigorate industry on technological innovation, and to reform the labor market through upskilling certain labor tasks, shrinking the gender gap, and redefining job competencies (Quezada et al., 2016).

\subsubsection{External population}

Indicators in the category of external population refer to impacts of the utilization of technology on the general public. At the project level, the application of advanced machinery contributes to the enhanced well-being of site neighbors by reducing noise and dust disturbance, and ease the burden to the local community by cutting down the environmental impacts (Bock and Linner, 2016b; Cousineau and Miura, 1998; Khoshnevis, 2004). Besides, innovative construction works supported by advanced machinery may require additional time and efforts to achieve governmental approval (Mahbub, 2008). At the corporate level, the investment in CAR can contribute to society by providing a wide array of high-level jobs in the high-tech industry. The necessity of human labor on the site can be dramatically reduced, whilst more high-skilled labor should be engaged in R\&D relevant works. Jobs and roles will be redefined to accelerate a socially sustainable development.

\subsection{Indicators of the technological performance}

In addition to TBL aspects, factors affecting the technological performance with respect to robustness, adaptability, and accessibility should also be assessed in the context of sustainability. The appropriate performance of the technology is the desirable condition to realize the positive influences on sustainability. As summarized in Table 4, these indicators are derived from the technology itself, but inextricably bound up with the environmental, economic and social performance of the project or the firm.

Table 4. Indicators of the technological performance of CAR.

\begin{tabular}{|c|c|c|c|}
\hline Categories & $\begin{array}{l}\text { Performance } \\
\text { Issues }\end{array}$ & Key Indicators & References \\
\hline \multirow{4}{*}{ Robustness } & \multirow{2}{*}{$\begin{array}{l}\text { Technology } \\
\text { validity }\end{array}$} & $\begin{array}{l}\text { Technology popularity and } \\
\text { reputation }\end{array}$ & $\begin{array}{l}\text { (Dunmade, 2002; Mahbub, } \\
\text { 2008) }\end{array}$ \\
\hline & & Technology readiness level & (Dunmade, 2002) \\
\hline & \multirow{2}{*}{$\begin{array}{l}\text { Technology } \\
\text { reliability }\end{array}$} & Mean time to repair & (Dunmade, 2002) \\
\hline & & Mean time between failures & (Dunmade, 2002) \\
\hline \multirow{4}{*}{ Adaptability } & \multirow{3}{*}{ Ease of use } & $\begin{array}{l}\text { Friendliness of interface with } \\
\text { manual workers }\end{array}$ & $\begin{array}{l}\text { (Bock and Linner, 2016a; } \\
\text { Warszawski and Navon, } \\
\text { 1998) }\end{array}$ \\
\hline & & $\begin{array}{l}\text { Interoperability with other } \\
\text { technologies }\end{array}$ & $\begin{array}{l}\text { (Bock and Linner, 2016a; } \\
\text { Warszawski and Navon, } \\
\text { 1998) }\end{array}$ \\
\hline & & Size, weight, power and mobility & $\begin{array}{l}\text { (Bock and Linner, 2016a; } \\
\text { Warszawski and Navon, } \\
\text { 1998) }\end{array}$ \\
\hline & $\begin{array}{l}\text { Flexibility of } \\
\text { technology }\end{array}$ & Reusability in different scenarios & $\begin{array}{l}\text { (Bock and Linner, 2015; } \\
\text { 2016a; 2016b; Dunmade, } \\
\text { 2002) }\end{array}$ \\
\hline
\end{tabular}




\begin{tabular}{|c|c|c|c|}
\hline & & Flexibility of function & $\begin{array}{l}\text { (Bock and Linner, 2015; } \\
\text { 2016a; 2016b; Dunmade, } \\
\text { 2002) }\end{array}$ \\
\hline & & The ability to future upgrades & $\begin{array}{l}\text { (Bock and Linner, 2015; } \\
\text { 2016a; 2016b; Dunmade, } \\
\text { 2002) }\end{array}$ \\
\hline \multirow{5}{*}{ Accessibility } & \multirow{3}{*}{$\begin{array}{l}\text { Technology } \\
\text { availability }\end{array}$} & Technology suppliers & $\begin{array}{l}\text { (Dunmade, 2002; Mahbub, } \\
\text { 2008) }\end{array}$ \\
\hline & & $\begin{array}{l}\text { Local availability of servicing } \\
\text { resources }\end{array}$ & $\begin{array}{l}\text { (Dunmade, 2002; Mahbub, } \\
\text { 2008) }\end{array}$ \\
\hline & & $\begin{array}{l}\text { Local availability of machine } \\
\text { components }\end{array}$ & $\begin{array}{l}\text { (Dunmade, 2002; Mahbub, } \\
\text { 2008) }\end{array}$ \\
\hline & \multirow{2}{*}{$\begin{array}{l}\text { Technology } \\
\text { acceptability }\end{array}$} & Public awareness level & $\begin{array}{l}\text { (Assefa and Frostell, 2007; } \\
\text { Dunmade, 2002; Mahbub, } \\
\text { 2008) }\end{array}$ \\
\hline & & $\begin{array}{l}\text { Availability of supportive } \\
\text { policies }\end{array}$ & $\begin{array}{l}\text { (Abbott, L.F., 2013; } \\
\text { Dunmade, 2002; Mahbub, } \\
\text { 2008) }\end{array}$ \\
\hline
\end{tabular}

\subsubsection{Robustness}

Robustness is the most elementary factor to ensure the functionality and quality of CAR to work as instructed, specifically considered in validity and reliability. Technology validity refers to the effectiveness of the technology to conduct the required tasks that can be assessed in relation to technology popularity, referring to the industrywide adoption and reputation (Dunmade, 2002; Mahbub, 2008) and technology readiness level, originally developed to evaluate the maturity level of a technology (NASA, 2012). Technology reliability is the consideration of the reliability of a machine during operation that can be rated in terms of mean time to repair and mean time between failures. Frequent breakdowns or long maintenance time could lead to poor economic performance (Dunmade, 2002).

\subsubsection{Adaptability}

To be better integrated into the traditional construction process, the "ease of use" is a significant concern. Automated and robotic technologies should be able to operate in a dynamic environment, and indicators should be considered user friendly interfaces with regard to human labor, and highly mobile (Bock and Linner, 2016a). To achieve a synergic relationship between robots and human workers, it is important that robotic technologies can seamlessly interact, collaborate, and be efficiently operated by human workers. Besides, the uptake of ICT systems is growing rapidly, and automated and robotic technologies should be capable of harmoniously interconnecting with these ICT tools, such as Building Information Modelling (BIM). Additionally, to work in the unstructured and dynamic site environment, construction robots need to be compact in size, light weight, stable, equipped with continuous power supply, and incorporate a high degree of mobility (Bock and Linner, 2016a; Mahbub, 2008).

Flexibility is considered as key for being able to unleash the economic potential of CAR (Pan et al., 2016), and is also an economically necessary (Dunmade, 2002). For instance, A/ROFs are hardly suited for buildings with different architectures (Bock and Linner, 2016b), single-task robots have fixed functions and their ability to adjust the complicated and dynamic construction workplace is limited (Warszawski and Navon, 1998). Meanwhile, automation in prefabrication often enables the use of multipurpose units to achieve flexible production in a sustainable manner, dramatically improving 
the efficiency and lowering the production cost (Bock and Linner, 2015). In this regard, reusability of the technology in different scenarios, the flexibility of functions, and the ability to allow for future upgrades should be included in the assessment framework.

\subsubsection{Accessibility}

The accessibility of technology is also essential for ensuring that the technology is available and acceptable within the context of use. The availability should be measured by available technology suppliers, and local availability of servicing resources and machine components (Dunmade, 2002). The acceptability can be determined by technology awareness level and availability of supportive policies (Dunmade, 2002). Public awareness and acceptance is often regarded as a key part of social sustainability in technology assessment (Assefa and Frostell, 2007; Mahbub, 2008). This study distinguishes it from intuitive social impacts from implementing the technology, as the influencing factor in technological performance category.

\section{Discussion}

\subsection{The overall framework}

As discussed above, an indicator framework of CARSAM is developed, which develops a systematic linkage between CAR and the sustainable realization of buildings. It facilitates a new pathway for achieving sustainability of buildings and offers an innovative method to assessing the performance of automation and robotics in the sustainability context.

CARSAM, as illustrated in Fig. 4, is comprised of two dimensions:

- Dimension 1 (radial dimension): Hierarchical dimension that represents how a particular indicator is linked to the higher level requirement of sustainability performance, and vice versa

- $\quad$ Dimension 2 (circular dimension: Tier dimension that describes how indicators are clustered to assess the particular performance issue, category, or sustainability target.

In detail, CARSAM is separated into four sections and four layers. The four sections distinguished by color are the environmental, economic, social and technological aspects that were considered to develop the indicator set. The four layers manifest the categories and indicators, with the inside part covering the highest level categories, the middle two parts covering the sub-categories, and the outermost layer containing the indicators. Specifically, 20 factor categories are allocated in the conceptual framework by considering impacts on environmental, economic, social at the project and corporate level, and technological performance at the technology level. Corresponding to the categories, 34 performance issues are extracted and 75 indicators are identified, together forming the framework of CARSAM. Based upon these indicators, a qualitative framework for the sustainable assessment of CAR is formulated. The indicators allow for the examination of how a particular automated or robotic technology, if implemented or invested, would impact on the environmental, economic and social performance at the project and corporate level, and how technological performance should be assessed synchronously. Further validation studies to test and detail the framework for practical use are required, and foreseen in our research plan (see Chapter 3). 

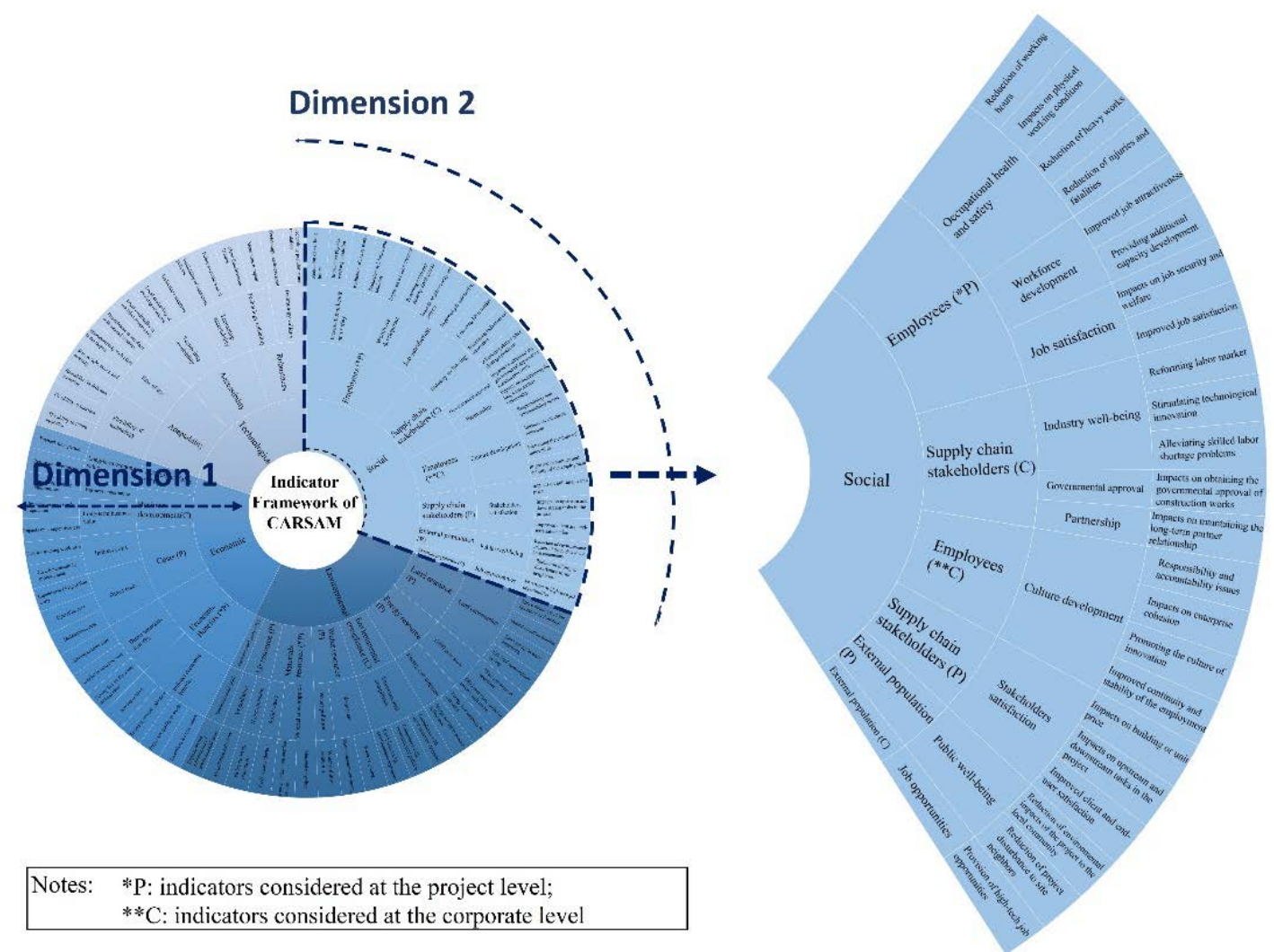

Fig. 4. The indicator framework of CARSAM is comprised of two dimensions integrating four sections and four layers, 20 factor categories, 34 performance issues, and 75 indicators.

\subsection{Future development}

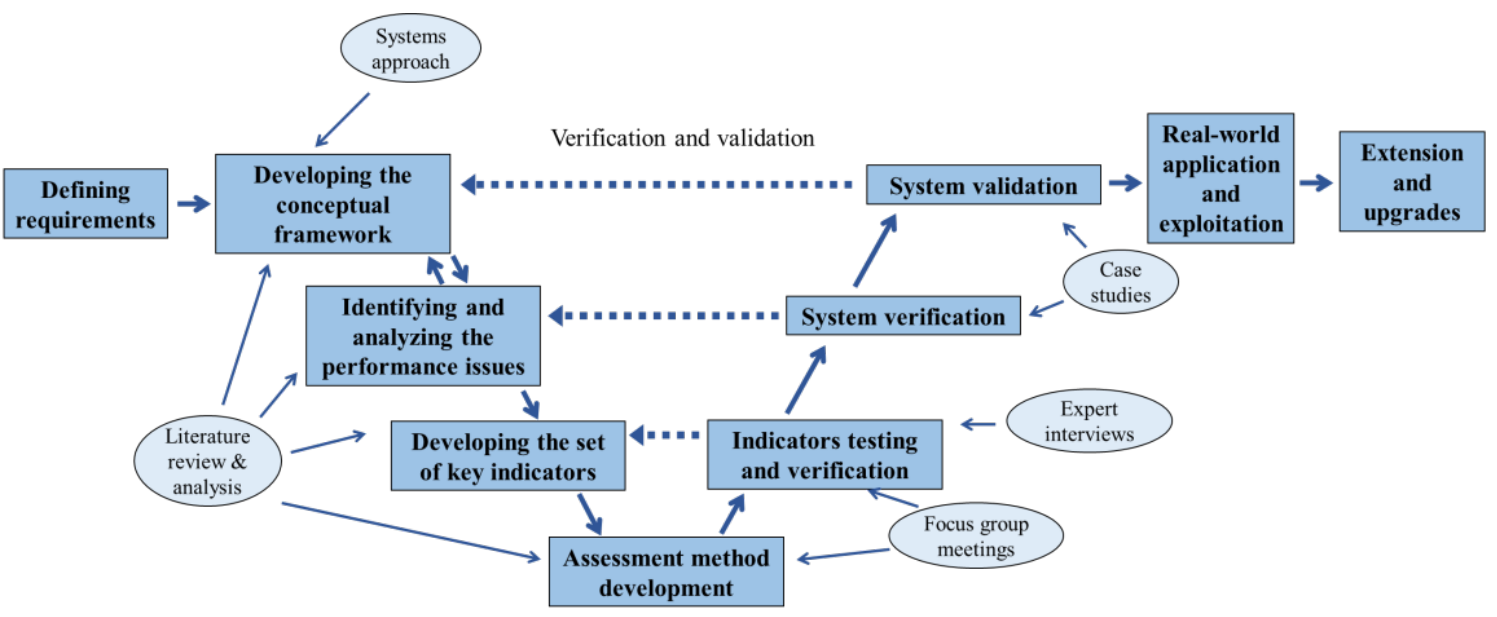

Phase One: Developing the indicator set for assessing construction automation and robotics
Phase Two: Developing and validating construction automation and robotics sustainability assessment method
Phase Three: Extending the method as supporting toolkit or standard

Fig. 5. The V-Model approach is utilized as the overall development method, and next steps with regard to the research presented will in particular focus on verification and validation. 
The presented work is the fundamental basis for the establishment of the full CARSAM assessment toolkit or standard, as the first phase illustrated in Fig. 5. Our overall research plan adopts the V-Model approach (see, for example, Firesmith, 2013; Leon Osborne et al., 2005), a systems engineering method used to systematically develop, implement and test robust solutions. The research presented in this paper (development of the initial indicator framework) foresees to translate the indicator framework into an assessment method which will then in several iteration cycles be verified (with stakeholders and case studies) and real world validated (in the industrial context) in order to achieve validity, practicality, and robustness.

For the framework to be exploitable and finally benefit technology providers, construction industry and the social and ecological situation, further development of the framework presented in this paper should focus on the following items:

1. First, quantifiable or qualitative description of the indicators and the weighting system should be developed to enable the framework to be fully applied in realworld projects as a decision supporting tool (Pan et al., 2016). This should be done by synthesizing the baseline targets of sustainable construction of buildings, good practices with the use of CAR gleaned from case studies, and suggestions from relevant experts. Intelligent algorithms can also be incorporated to prop up the assessment-based decision making.

2. Second, the framework could serve as a toolkit for different scopes and context of use. Pan (2010) argued that different project requirements might affect technology preferences, and organizational strategies for innovation are different. Hence, further development of the toolkit should embed flexibility and optional strategies to fit the different purposes of assessment.

3. Third, the framework could be further developed into concrete standards with the focus on technology. It could complement and extend existing assessment methods of green building, such as LEED and BREEAM, in which priority has been given to environmental performance and buildings (BREEAM, 2014; LEED, 2014). Thus, the CARSAM indicators should be taken further and refined for standardized use, which can not only allow for comparative studies, but contribute to knowledge sharing among different projects.

To realize the sustainability benefits associated with CAR, the industry should devise an innovative business model that identifies new stakeholder groups and cultivates collaboration platforms of machinery sharing. The proposed framework might also be able to explicate the underlying reasons of the technology diffusion. According to Mahbub (2008), more than 200 prototypes of construction robots have been developed since the 1980s, but very few have been commercialised and widely used. To better understand why these technological breakthroughs fail to be diffused, this framework could facilitate a comprehensive sustainability-oriented examination. Therefore, pilot case studies are pertinent not only to verify the effectiveness of the framework, but to suggest feasible routes for future construction technology development.

\section{Conclusions}

Sustainability considerations require guidelines for conducting construction automation technology related sections and decisions in tune with global sustainability development trends. The recent significantly growing demand for sustainability has the 
potential to serve as the necessitated trigger for CAR's large-scale deployment and in that context, systematic decision making guidance for construction industry is missing. The research presented in this paper has made a first step to fill this research gap by developing for the first time a consistent framework of indicators for assessing the sustainability performance of utilizing CAR for buildings. In this paper, therefore, the indicator framework for CARSAM has been developed, which provides the metrics for sustainability assessment of CAR, contributing to a holistic understanding of the impacts of CAR on sustainability, and offering guidance for automated and robotic technology options for building projects or construction companies in a sustainable and systematic manner. Being aware that the proposed study is yet far from delivering a complete, all embracing assessment tool for real-world application (which is the ultimate goal of the research group), future research is planned. The overall goal of our research is to develop, through CARSAM, a robust and reliable assessment method that can be used in the industrial context to assess the sustainability of building construction projects that consider using CAR. Beyond the development of the initial indicator framework (presented in this paper), our research plan (following the V-Model approach) foresees to translate the indicator framework into an assessment method which will then in several iteration cycles be verified and validated in real world.

\section{Acknowledgements}

The work presented in this paper is partly financed by a grant from the Germany / Hong Kong Joint Research Scheme sponsored by the Research Grants Council of Hong Kong (Reference No. G-HKU704/15) and the German Academic Exchange Service (DAAD Grant No. 57217359).

\section{References}

Abbott, L.F., 2013. Political Barriers to Housebuilding in Britain: A Critical Case Study of Protectionism and its Industrial-commercial Effects. Industrial Systems Research.

Assefa, G., Frostell, B., 2007. Social sustainability and social acceptance in technology assessment: A case study of energy technologies. Technology in Society 29, 63-78.

Balaguer, C., Abderrahim, M., Navarro, J., Boudjabeur, S., Aromaa, P., Kahkonen, K., Slavenburg, S., Seward, D., Bock, T., Wing, R., 2002. FutureHome: An integrated construction automation approach. IEEE Robotics \& Automation Magazine 9, 55-66.

Berardi, U., 2013. Clarifying the new interpretations of the concept of sustainable building. Sustainable Cities and Society 8, 72-78.

BERTIM, 2016. http://www.bertim.eu/

Bock, T., 2015. The future of construction automation: Technological disruption and the upcoming ubiquity of robotics. Automation in Construction 59, 113-121.

Bock, T., Linner, T., 2012. Evolution of large-scale Industrialization and Service - Innovation in Japanese Prefabrication Industry. Journal of Construction Innovation: Information, Process, Management 12, 1471-4175.

Bock, T., Linner, T., 2015. Robotic Industrialization: Automation and Robotic Technologies for customized Component, Module and Building Prefabrication. Cambridge University Press, Cambridge.

Bock, T., Linner, T., 2016a. Construction Robots: Elementary Technologies and Single-TaskConstruction Robots, Cambridge.

Bock, T., Linner, T., 2016b. Site Automation: Automated/ Robotic On-site Factories. Cambridge University Press, Cambridge.

BREEAM, 2014. Building research establishment environmental assessment method, UK. 
Brent, A.C., Pretorius, M.W., 2008. Sustainable development: A conceptual framework for the technology management field of knowledge and a departure for further research. South African Journal of Industrial Engineering 19, 31-52.

Brent, A.C., Van Erck, R.P., Labuschagne, C., 2006. Sustainability cost accounting-Part 1: a monetary procedure to evaluate sustainability of technologies in the South African process industry.

Brundtland, G.H., 1987. Report of the World Commission on environment and development:" our common future". United Nations.

Castro-Lacouture, D., 2009. Construction automation, Springer Handbook of Automation. Springer, pp. 1063-1078.

Cousineau, L., Miura, N., 1998. Construction robots: the search for new building technology in Japan. ASCE Publications.

De Beer, J., Worrell, E. and Blok, K., 1998. Future technologies for energy-efficient iron and steel making. Annual Review of Energy and the Environment, 23(1), pp.123-205.

Dunmade, I., 2002. Indicators of sustainability: assessing the suitability of a foreign technology for a developing economy. Technology in Society 24, 461-471.

Firesmith, D., 2013. Using V Models for Testing. Carnegie Mellon University.

GRI, 2013. G4 Sustainability Reporting Guidelines: Reporting Principles and Standard Disclosures, Global Reporting Initiative, Amsterdam.

Goodier, C.I., Pan, W., 2010. The future of UK housebuilding, RICS research report. RICS, London.

Goulding, J.S., Pour-rahimian, F., Arif, M., Sharp, M., 2012. Offsite construction: strategic priorities for shaping the future research agenda. Journal of Architectoni. ca 1, 62-73.

Hasegawa, Y., 1999. Robotization in Construction. Kogyo Chosakai Publishing, Tokyo.

Hill, R.C., Bowen, P.A., 1997. Sustainable construction: principles and a framework for attainment. Construction Management \& Economics 15, 223-239.

Hong, J., Shen, G.Q., Feng, Y., Lau, W.S.-t., Mao, C., 2015. Greenhouse gas emissions during the construction phase of a building: a case study in China. Journal of Cleaner Production 103, 249-259.

ISO, 2008. ISO 15392:2008 Sustainability in building construction -- General principles, Geneva.

ISO, 2011. ISO 21929-1:2011 Sustainability in building construction -- Sustainability indicators -- Part 1: Framework for the development of indicators and a core set of indicators for buildings, Geneva.

Khoshnevis, B., 2004. Automated construction by contour crafting-related robotics and information technologies. Automation in Construction 13, 5-19.

Kibert, C.J., 1994. Establishing principles and a model for sustainable construction, Proceedings of the First International Conference on Sustainable Construction. Tampa Florida, November, pp. 6-9.

Kumar, V.P., Balasubramanian, M., Raj, S.J., 2016. Robotics in construction industry. Indian Journal of Science and Technology 9.

Labuschagne, C., Brent, A.C., Van Erck, R.P., 2005. Assessing the sustainability performances of industries. Journal of Cleaner Production 13, 373-385.

Lee, S., Pan, W., Linner, T., Bock, T., 2015. A Framework for Robot Assisted Deconstruction: Process, Sub-systems and Modelling, Proceedings of the 32nd International Symposium on Automation and Robotics in Construction and Mining (ISARC2015), Oulu, Finland.

Lee, U.-K., Yoo, W.S., An, S.-H., Doh, N., Cho, H., Jun, C., Kim, T., Lee, Y.H., 2013. Performance assessment model for robot-based automated construction systems. Journal of the Korea Institute of Building Construction 13, 416-423.

LEED, 2014. LEED - Leadership in energy and environmental design: green building rating system v4 ed. US Green Building Council.

Maclaren, V.W., 1996. Urban sustainability reporting. Journal of the American planning association 62, 184-202.

Mahbub, R., 2008. An investigation into the barriers to the implementation of automation and robotics technologies in the construction industry. Queensland University of Technology. 
NASA, 2012. Technology Readiness Level. [Online] Available at: https://www.nasa.gov/directorates/heo/scan/engineering/technology/txt_accordion1.html

Neelamkavil, J., 2009. Automation in the prefab and modular construction industry, 26th Symposium on Construction Robotics ISARC.

Pan, M., Linner, T., M., C.H., Pan, W., T, B., 2016. A Framework for Utilizing Automated and Robotic Construction for Sustainable Building, CRIOCM 2016, Hong Kong.

Pan, W., 2010. Strategies for managing innovation in UK housebuilding. Engineering, Construction and Architectural Management 17, 78-88.

Pan, W., Garmston, H., 2012. Building regulations in energy efficiency: Compliance in England and Wales. Energy Policy 45, 594-605.

Pan, W., Ning, Y., 2014. Dialectics of sustainable building: Evidence from empirical studies 1987-2013. Building and Environment 82, 666-674.

Pan, W., Ning, Y., 2015. The dialectics of sustainable building. Habitat International 48, 5564.

Paris Agreement, 2015. United nations framework convention on climate change. Paris, France.

Paulson Jr, B.C., 1985. Automation and robotics for construction. Journal of Construction Engineering and Management 111, 190-207.

Phaal, R., Farrukh, C.J., Probert, D.R., 2004. A framework for supporting the management of technological knowledge. International Journal of Technology Management 27, 1-15.

Qi, G., Shen, L., Zeng, S., Jorge, O.J., 2010. The drivers for contractors' green innovation: an industry perspective. Journal of Cleaner Production 18, 1358-1365.

Quezada, G., Bratanova, A., Boughen, N., Hajkowicz, S., 2016. Farsight for construction: Exploratory scenarios for Queensland's construction industry to 2036. CSIRO, Australia.

Reed, M.S., Fraser, E.D., Dougill, A.J., 2006. An adaptive learning process for developing and applying sustainability indicators with local communities. Ecological Economics 59, 406418.

Sandberg, M., Johnsson, H., Larsson, T., 2008. Knowledge-based engineering in constructionthe prefabricated timber housing case. Journal of Information Technology in Construction (ITcon) 13, 408-420.

Sarkis, J., Presley, A., Meade, L., 2010. Benchmarking for sustainability: an application to the sustainable construction industry. Benchmarking: an international Journal 17, 435-451.

Singh, R.K., Murty, H.R., Gupta, S.K., Dikshit, A.K., 2009. An overview of sustainability assessment methodologies. Ecological Indicators 9, 189-212.

Skibniewski, M.J., 1992. Current status of construction automation and robotics in the United States of America, The 9th International Symposium on Automation and Robotics in Construction, pp. 17-26.

Son, H., Kim, C., Kim, H., Han, S.H., Kim, M.K., 2010. Trend analysis of research and development on automation and robotics technology in the construction industry. KSCE Journal of Civil Engineering 14, 131-139.

Struková, Z., Liška, M., 2012. Application of automation and robotics in construction work execution. AD ALTA: Journal of Interdisciplinary Research 2, 121-125.

United Nations, 2007. Indicators of sustainable development: Guidelines and methodologies. United Nations Publications.

United Nations, 2015. Transforming our world: The 2030 agenda for sustainable development. United Nations, Department of Economic and Social Affairs, New York.

Vähä, P., Heikkilä, T., Kilpeläinen, P., Järviluoma, M., Gambao, E., 2013. Extending automation of building construction-Survey on potential sensor technologies and robotic applications. Automation in Construction 36, 168-178.

Wakisaka, T., Furuya, N., Inoue, Y., Shiokawa, T., 2000. Automated construction system for high-rise reinforced concrete buildings. Automation in Construction 9, 229-250.

Warszawski, A., 2003. Industrialized and automated building systems: A managerial approach. Routledge.

Warszawski, A., Navon, R., 1998. Implementation of robotics in building: Current status and future prospects. Journal of Construction Engineering and Management 124, 31-41. 
Yuan, H., 2013. Key indicators for assessing the effectiveness of waste management in construction projects. Ecological Indicators 24, 476-484.

Zavadskas, E.K., 2010. Automation and robotics in construction: International research and achievements. Automation in Construction 19, 286-290.

ZERO-PLUS, 2016. http://www.zeroplus.org/.

Zhao, Z.-Y., Zhao, X.-J., Davidson, K., Zuo, J., 2012. A corporate social responsibility indicator system for construction enterprises. Journal of Cleaner Production 29, 277-289. 